\begin{abstract}
Alexia Vassilatos
Alexia Vassilatos is a senior lecturer and Head of French and Francophone Studies at the University of the Witwatersrand. Her research focuses on francophone literature and its dialogue with African and Indian Ocean literatures.

Email: Alexia.Vassilatos@wits.ac.za
\end{abstract}

\section{The transculturation of Thomas Mofolo's Chaka}

\title{
The transculturation of Thomas Mofolo's Chaka
}

Often, literary cultures from Anglophone Africa and Francophone Africa are treated as separate intellectual spheres. In this paper, I seek to understand the dialogue between these cultures. Thomas Mofolo's novel Chaka (1925), drawn from oral lore and written in Sotho by a Sotho writer, is about the life and times of the founder of the Zulu nation, King Chaka. I will show that Chaka is a transcultural text, which is at the source of a complex intellectual relationship between Southern Africa and Francophone Africa within the literature on Chaka. In particular, I am interested in the way in which an African writer from Lesotho could have shaped another African writer's ideas about the Zulu King-Senegalese poet Léopold Sédar Senghor-which, in turn, triggered a series of Africanist interpretations and rewritings. Through these multiple texts the impact of Chaka on African literature and ideology has been immeasurable. I will discuss Thomas Mofolo's novel contribution to Chaka's mythical status in Francophone African literature and Africanist ideology, mainly by way of the Negritude movement. In my analysis I postulate that the complexity of Mofolo's text and its transculturation stems from the novel's many forms/(trans)form(ations). Keywords: Chaka, Francophonie, Léopold Sédar Senghor, Negritude, Thomas Mofolo, transculturation,

\section{Introduction}

"Transculturation" is a term first coined by Cuban sociologist Fernando Ortiz to encompass and "to replace the paired concepts of acculturation and deculturation that described the transference of culture in reductive fashion" between colonies and metropolis (Pratt 228). Transculturation, in Attwell's words, suggests "multiple processes, a dialogue in both directions" (Attwell 18). In the case of Thomas Mofolo's Chaka (1925), transculturation takes place through its various rewritings and translations. The transference of culture does not follow a linear (colonies/metropolis) path but, rather, Chaka becomes transcultural through the variety of cultures it comes into contact with and which are not necessarily delineated by imperial relationships.

I argue that Mofolo's text engenders a complex narrative of cultural exchanges that, thanks to Léopold Senghor, extends beyond the Senegalese poet to include a number of Francophone African writers such as Seydou Badian from Mali or Congolese poet and playwright Tchikaya U'Tam'Si, for instance. Through its contact with Negritude, the subject of Mofolo's text becomes transculturated back into Southern Africa, where writers of the Black Consciousness such as Steve Biko, find resonance with its ideological precepts. 


\section{Thomas Mofolo's Chaka}

Chaka was Mofolo's third novel and, like the previous two, was published by the Paris Evangelical Mission (PEMS) Press in Morija, Lesotho.

On a very basic level, the novel is about Chaka's journey of self-discovery and eventual downfall, his psychological evolution resting at the core of the narrative. The story begins with the circumstances of the illegitimate conception and birth of the hero and ends with his descent into madness and his fratricidal death. For succession reasons, Senzangakhona, Chaka's father, is persuaded to abandon his son who, as a result, knows a hard life.

A key episode that marks Chaka's destiny happens when he is visited, in a dream-like passage, by the King of the Deep Pool. This mysterious snake-like creature "gazes deeply into [Chaka's] terrified eyes" to foretell his great destiny in the form of a praise poem (25).

Chaka also meets Isanusi the diviner, a character central to understanding Chaka's rise to power and his subsequent moral decline. Isanusi's importance for the psychological and narrative complexity of Mofolo's prose cannot be overlooked. He is the most elusive character of all and seems to know Chaka, even though they have never met. Some have seen in Isanusi not a physical character but a symbol of the evil side of Chaka's psyche. For others, he is Chaka's powerful, metaphysical double. For others still, he is "an archetypical symbol of the devil" (Burness 11), an interpretation based no doubt on Mofolo's Christian beliefs. But interpreting Isanusi as pure evil or, on the contrary, as wise, is reductive since it ignores Isanusi's essential ambiguity and Mofolo's complex characterisation (Lazarus 53).

Chaka accepts Isanusi's help in exchange for his unconditional submission to the diviner and his life is changed for ever. When his father dies, Chaka is installed as his successor and when in turn Dingiswayo is killed, he acquires the good king's kingdom as well. The entire Chapter 17 is dedicated to a meticulous enumeration of the reforms, mainly of a military nature, brought about by Chaka to the newly founded Zulu nation.

Chaka's thirst for power now dominates all other considerations. His numerous crimes as well as the massacres committed against his own people are listed. In this part of the novel, Mofolo also describes the impact of the Mfecane ${ }^{1}$ on everything (153).

The end of the novel deals with Chaka's progressive decline. "Painful Dreams" 2 (Chapter 24) recounts how Chaka is plagued by visions and nightmares and in "Donga lukaTatiyana" (Chapter 25) Chaka relives key events in his life, his dreams causing him pain and remorse.

The theme of 'vision' is an unremitting motif in the novel and its paroxysm is reached at the end of the story. By the last chapter, "The End of Chaka", Chaka has become weak, feverish and confused. The vocabulary of vision is dominant here. 
As his powers deteriorate, Chaka's vision gets blurred and confused, images fleet through his mind, his deeds pass before his eyes etc. (159-66).

The novel ends in an epic manner, with a proverb in praise of the formidable Zulu nation "in the days of Chaka" (168) as well as a traditional moral—that all evil gets punished.

The last image Chaka 'sees', before his brothers kill him, is that of Isanusi and his aides, in the distance-present to claim their price? His last words, a vision in themselves, are: "You are killing me in the hope that you will be king when I am dead, whereas you are wrong, that is not the way it will be because the umlungu, the white man, is coming, and it is he who will rule you, and you will be his servants" (167). As will be shown, the importance of Chaka's visionary quality is central to the novel's later transculturation.

The novel was written at a time of great political turmoil in Southern Africa. David Attwell endeavours to place Chaka or, more precisely, the writing of Chaka into its proper historical context. This is crucial because in Chaka, the impulses of Mofolo's writing seem transcended into what is a complex historical political and psychological novel.

Although the dates of Mofolo's travels to Natal (where he was travelling gathering information for the novel) cannot be ascertained, all evidence points to the period of 1908-9, which is relevant in view of the aftermath of the Bambata rebellion (Attwell 55). A significant aspect of the rebellion ${ }^{3}$ which would have a bearing on Mofolo is the ideological climate of the time: that of the attempt to assert "the status and meaning-for Zulus as well as outsiders_-of the idea of Zulu nationhood, in particular that of the royal family, 'the house of Chaka'" (Attwell 57, my emphasis).

Attwell suggests that Mofolo, in writing Chaka, was engaged in the "task of historical and cultural diagnosis", using circumstantial details to arrive at the historical truth (Attwell 59), which was, at that historical juncture, that of Zulu (African) nationalism and its subjugation by colonial powers. Mofolo, it is clear, held some ideas that represent evidence of his nascent ideological awakening and resistance in Black Southern Africa. ${ }^{4}$ The notion is echoed by Roux for whom the Bambata rebellion engendered a shift in South Africa's (political) history because it clearly marked the advent of a new period, that of "the struggle for national liberation and democratic rights within a framework of present-day South Africa" (Roux 87). This is plainly evident in Mofolo's novel. Although the narrator bestows a strong moral judgment on his character's cruelty and greed, he undeniably admires Chaka politically. Chaka's nation-building endeavour and military achievements, which Mofolo calls "acts of great significance" (114) are enumerated in admiring and hyperbolic terms. Mofolo's aversion for Chaka's character combined with his admiring tone contributed to the novel's complexity and Chaka's ambiguity. From there stemmed Senghor's admiration for Mofolo, as a writer first and foremost, and for Chaka, his multifaceted hero. 
In this context, Chaka served as a retrospective on the Africa of the past, in order to reflect on its future direction. Mofolo's writing parallels one of Negritude's central tenets, what in Senghor and others', is expressed by the recurrent idea of return. In order to recapture an identity that was destroyed by white imperialism and the colonial experience in particular, the 'black man' needs to (re)turn to his own historical and cultural sources. In other words, recalling a pre-colonial Africa is a means to deal with present circumstances and envisage a new future. The African Francophone writers who read Chaka found inspiration in Mofolo because his concerns, in a panAfricanist revelation, echoed theirs, albeit at a different historical moment. Mofolo was undeniably "concerned with the nature of power and the destiny of African peoples. Because of this, his novel has much in common with contemporary African literature" (Burness 14).

Burness sees Mofolo's modernity, as it is expressed in the novel Chaka, encapsulated in the character of Dingiswayo, ${ }^{5}$ who "is a thinker who tries to understand history and seeks above all the welfare of his people. But historical forces and human nature are such that he fails. This is his tragedy in a novel that deals primarily with a man that is very much unlike him" (Burness 14). This comment is enlightening because Burness hints at the possibility that the Francophone writers who read Mofolo drew from this particular theme in the novel and made it the focus of their own versions, in accordance with their own political and personal concerns.

\section{Senghor's Chaka}

Léopold Sédar Senghor's Chaka was first published in 1951 by Présence Africaine, ${ }^{6}$ at a time when Europe was only just seeing the end of a devastating war, and African countries had begun to claim their right to self-determination from their colonising rulers.

Comparatively little has been written about Senghor's poem. Chaka was, at best, denied the critical attention customarily given to the literary and ideological value of Senghor's work and, at worst, gravely misunderstood by the public at large.

In my view, the readers and critics of Senghor's Chaka could not reconcile what its author represented - one of the founder of the Negritude movement and its most reconciliatory spokesperson-with what the poem's main protagonist symbolized: an expansionistic and bloodthirsty leader who evoked strong parallels with Hitler (Jouanny 90).

A crucial element lacking from this rather monolithic response to Senghor's poem is the understanding of its source and its impact on the Senegalese poet: Thomas Mofolo's novel Chaka. Certainly, by reading Mofolo whom he saw as a pioneering modern African writer, ${ }^{7}$ Senghor was inspired to make Chaka one of his most lyrical emissaries of Negritude in his poetic rewriting of the novel.

I wish to illustrate that understanding Senghor's reading of Mofolo is about shedding light on the dynamic of a dialogue in the direction most obviously ignored by 
literary theories: not between metropole and peripheries but within the peripheries, no matter how removed historically and culturally from one another they may appear. In essence I demonstrate that Senghor's poem is a transcultural version of Mofolo's novel.

For Senghor, mythology serves to illustrate our inner life by giving it meaning (Senghor 190). In this sense, the figure of Chaka has provided him with fertile mythical possibilities for his own personal epistemology of Negritude, where his poetic representation of Chaka amalgamates that of Chaka as lover (of Africa/the African woman - a thematic which needs its own thorough exploration), Chaka as an African Christ and martyr fighting injustice and Chaka the visionary king whose sacrificial death brings the rebirth of the continent and with it the promise of a new world order.

Certain elements in the poem allude directly to the contents of Mofolo's novel even when their connotation/interpretation may sometimes differ. This is the case for instance of the oral elements of the text. Firstly, Chaka is, as per the author's indication a "dramatic poem for several voices" (142). Mofolo's narrative is strewn with praise phrases and praise poems. Senghor's use of the Bayete greeting, a laudatory praise destined for Chaka, is a striking parallel between novel and poem. The poet cites the phrase directly from Mofolo's text (149-51) and it is repeated by the Chorus, that is to say by many voices at once, thus multiplying the references to Mofolo's text as well as deepening the oral dimension of the poem.

Representing his hero in a Christ-like manner at the moment of crucifixion may appear paradoxical but this is how Senghor in fact intrinsically connects Chaka to Africa in his poem:

I have lived the myth of Africa in all its essence. On the one hand, it is an Africa who, like the Christ, has been crucified in the last five centuries by the Slave Trade and colonialism. But it is also an Africa redeemed, whose resuscitation will greatly contribute to the germination of a panhuman civilization. Similarly, I have lived Africa as the Black Continent, Africa as Femininity, Love, and Poetry ... (Senghor 361).

Here Senghor speaks of his poetic awakening and of his poetic experience of Africa or, rather, of the myth of Africa. This inspiration led him to his own great themes of Negritude. Among these is the theme of an idyllic, highly romanticised, pre-colonial Africa as well as that of a wounded Africa whose people have become martyrs-the poem is dedicated to the "Bantu martyrs of South Africa". But by embracing its own Negritude, and through sacrifice, the continent can heal. The idea of rebirth, which is leitmotiv in Senghor's poetry, is expressed in Chaka with an abundance of images of ashes, new dawns and rebirths. Chaka is the dutiful king, whose life he dedicated to preparing the metaphorical fields. Chaka explains, as he draws his last breath, that he has led the way, through heavy sacrifice, for a new dawn for his people: "[A]nd from the drum, may there arise over a new world a new sun" (154, my emphasis). The 
image of a new sun/new dawn is central to Senghor's rhetoric for he believes that with the 'black man's' re-affirmation of the values lost under white domination will come a new understanding-“new dawn opening my people's eyes" (154).

Senghor's Christological transformation of Chaka as a metonymy for the martyrdom of Africa is in keeping with idea of transculturation since it aims to reconsider history's accepted narrative(s) and deviate, where appropriate, from the usual pejorative lines of reasoning, to new possible interpretation(s). By revisiting the past, Senghor sets up a dialogue between the Zulu king and his white accusers (represented by the White Voice) where both parties can plead their case. Significantly, whereas Mofolo's novel is in the third person, Senghor's Chaka is in the first and second, except when Chaka is being praised. This gives the main protagonist his own voice, without denying his opponents their own, in this staged historical trial. The White Voice tries to reason with Chaka rationally, revealing undeniable (and objective) facts: he has killed and others have killed in his name. The White Voice, in its own subjectivity, does not see Chaka as a redemptive force but as a butcher. Although Chaka does not deny any of his crimes (since he cannot), he proposes a different way of looking at them, of looking, in fact, at history (since he can). Senghor, through his character's plea, suggests that there is an alternative epistemology, not the White Voice's or the West's, which has suppressed all others, but that of Chaka's, which, in the poem, dovetails that of Negritude.

Senghor's Chaka, in a poetic anachronism, bears witness to the devastation of colonialism. The destruction is total and does spare neither people nor nature. The perpetrators are not just the colonialists but include the proponents of the nascent apartheid system as well: "Peoples of the South, in the shipyards, the ports and the mines and the mills /And at evenings segregated in the kraals of misery" (147, my emphasis). In those unambiguous verses Senghor refers to Southern Africa directly, using words (in italics) specific to the South African context.

Mysteriously Senghor's criticism of the apartheid regime does not figure in the existing critical literature. Perhaps this stems from the fact that most readers confine themselves to interpreting the text within the historical context of Chaka's life, seeing the treatment of colonialism as an anachronism that only momentarily interrupts the temporal linearity of the narrative. This, however, would be an incomplete reading of Chaka since the hero of the poem has many facets. His function as an African hero from the past that becomes instrumental in the fight against oppression in the present-including the apartheid regime—cannot be overlooked, because Chaka represents one of the most explicit thematic treatments of the exploitation of Africa and Africans in Senghor's poetry, which resides at the heart of his Negritude.

Our reading of Senghor's Chaka elucidates Chaka's roles in the poem as, amongst others, a sacrificial black Christ but also as an anachronistic emissary of Negritude speaking against the evils of the colonial enterprise on the continent as a whole and 
against racial segregation in Southern Africa in particular. Senghor's rather strong, albeit poetic, condemnation of racial segregation in South Africa is an acknowledgement of his debt to Mofolo, whose text put in place the possibility for a conversation from within Africa, between Africans and about Africa.

\section{Francophone adaptations and pan-Africanist visions}

A thorough literary analysis of each of the African Francophone adaptations of Mofolo's text is beyond the scope of this paper. Because of this I have chosen to focus on Malian writer Seydou Badian Koyaté's La mort de Chaka (1961) because it is generally illustrative, in my opinion, of most Francophone interpretations of Chaka or, at least, of their most salient thematic and stylistic characteristics. I will however also consider other texts (albeit not all of them) that have been inspired, some to a greater extent than others, by Mofolo's novel and Senghor's poem. These are Condetto NénékhalyCamara's Amazoulou (1970), Djibril Tamsir Niane's Chaka (1971), Agbota Zinsou On joue la comédie (1975), Tchikaya U'Tam'Si's Le Zulu (1978) and, lastly, Marouba Fall's Chaka ou le roi visionnaire (1984).

Two salient observations need to be made at this point. Firstly, just like Mofolo and Senghor, each of the authors cited made a conscious choice to ensure continuity with oral tradition in their texts. It is no coincidence, thus, that all the African Francophone re-writings of Chaka are plays-with the exception of Senghor's poetic drama. ${ }^{8}$ Francophone African writers chose to retell Mofolo's story in the form of plays or poetic drama and in turn made a conscious decision to reconnect that form (partly inherited from the West) to more African "ancient theatrical forms" (Conteh-Morgan 30) which belong to the realm of oral narrative. An immediate demonstration of this is the inclusion, in many of the versions discussed, of a griot or a character with a similar function such as the 'Leader of the Chorus' in Senghor's poem or Isanoussi in Badian's play.

In choosing a literary genre that allows the inclusion of elements drawn from traditional theatre, these authors make the conscious choice, nationalistic in nature, to contribute to the rediscovery (or the preserving) of African values, art and culture. This intellectual position is inherited from Negritude whose primary goal is the recovery of the 'black man's' identity and culture-what Senghor calls the quest for the 'Graal-Negritude'.

My second and closely related point refers to the role of history in such a quest. Much like for Mofolo himself, the past serves these writers with allegories for Africa's pre-colonial glory and current politics simultaneously. So it is that historical accuracy in these plays is only secondary to their authors' political motivations. Yet Francophone authors have retained the strong Shakean identity and its correlated Zulu politics from Mofolo's novel which have served them to advance pan-Africanist ideals or lament, whichever the case, their loss. 
Badian's play is the story of the death of Chaka. In it, Chaka has been governing his newly established kingdom with an iron fist and his generals, tired of the warring ambitions and authoritative ways of their king, meet to discuss his demise.

The main tension in the narrative resides around the generals debating the vices and virtues of their leader. For some, Chaka is nothing but a bloodthirsty tyrant driven by greed while others remain unconditionally loyal to the king, going as far as excusing him for the massacres of his own brothers-in direct reference to Mofolo's Chapter 19.

Amongst others, Badian retains Mofolo's episode of the visitation of the King of the Deep Pool. The meeting with the creature serves to highlight Chaka's inherent good intentions and his strong socialist aspirations. In Badian's re-writing, The King of the Deep Pool offers Chaka all the glory and riches of the world but, instead of greedily accepting the terms of the pact, Chaka claims that he only desires the greatness and happiness of his people. In direct contrast to Mofolo's Chaka, who is a man without temperance, driven by his insatiable thirst for power, Badian's hero is a selfsacrificial, nationalist-socialist leader whose murder becomes an act of treason against a great leader (Mabana 106-7). Couzens offers the following insight into The Death of Chaka's central theme: "[Badian's] theme is the struggle between the charismatic nationalist leader, who has united his people in the face of terrific odds [...] while sacrificing his personal pleasures, and the divisive forces of the elite who have risen with him and who now wish to live the good life rather than pursue nation-building..." (Couzens 187, my emphasis).

There is no doubt that Badian heard, just as Senghor before him, a voice of protest in Mofolo's Chaka. Just as Chaka warns of the advent of white imperialism on the continent in Mofolo's text, so does Badian's hero anticipate troubling times as he lay dying: "Our land will be lost soon [...] we will know a life without light, a life of torture and humiliation [...] But I, Chaka, am convinced that at the end of this night, you, my people, will be able to come through this troubling time by relying on your own virtues ..." (Badian 238).

From this, it is clear that a common thread between the Francophone re-writings of Mofolo's Chaka is that they retain Chaka's visionary qualities. As demonstrated earlier, Mofolo's thematic and narrative construction has much to do with this. Mofolo effectively renders the importance of seeing/eyes, visions and dreams. Chaka's superiority in life was precisely that he was a visionary-in the "daytime dreams he dreamed with his eyes wide open" (167). This attribute has been fundamental to the Negritude writers' reading and rewritings of the novel. All Francophone interpretations highlight Chaka's visionary quality. Fall's title, Chaka ou le roi visionnaire and the repetition of Chaka's 'I saw' in Senghor's poem are two immediate illustrations. Also, most of the texts begin precisely where Mofolo left off, at the moment of Chaka's death, when the hero proclaims his dark vision for the future of Africa. 
The re-interpretation of (Mofolo's) Chaka serves African Francophone writers who have read him, in a response to Mofolo's idiosyncratic expression of his own concerns, to express, in turn, their own individual visions and desires for the continent during and after all forms of white domination-slavery, colonialism as well as apartheid.

La mort de Chaka was published a year after Mali's independence. The writer's circumstances and his political involvement in the birth of his country's first independent socialist government puts his play in a singular perspective. Badian warns his readers/his audience against the careless governance of those who feel they deserve to reap the rewards of hard work to the detriment of the greater good.

Badian's play is perhaps one of the most faithful rewritings of Chaka. Badian has included many original details from Mofolo's novel such as for instance the name of tribes and regiments used by Mofolo and even a reference to the Mfecane in the opening of the play. This is also true for the killings at Tatiyana, the meeting with the King of the Deep Pool as well as the episode where Chaka heroically saves a young woman from a hyena.

Yet, one of Badian's crucial departures from Mofolo's text is that of Isanusi's role. Whereas the diviner is the cause of Chaka's downfall in the novel, his function, in the play is the radical opposite. Isanusi is a benevolent character, a wise elder in the traditional African sense, to whom Chaka looks for wisdom. This reversal of Isanusi's narrative function in the Malian writer's version stems from two simultaneous intentions, both political in nature.

Firstly, Badian shows a clear desire for a text whose form is reminiscent of the thêâtre naturel ${ }^{9}$ of traditional African oral literature. Badian, who himself comes from a long line of griots, chooses a literary form that can be performed orally. This desire to produce a work that is authentic and not elitist, in a 'popular' genre that is accessible to all, is in keeping with his political convictions.

Isanusi, as the type-cast village elder (or sage) is the keeper of tradition and thus represents the wisdom of old. In changing Isanusi's function in the intrigue to the protector of the integrity of his society instead, Badian achieves his socialist objectives while at the same retaining an important figure of many African societies. This way, if La mort de Chaka was to be performed for an audience, the spectators would be able to hear Badian's message for the need for temperance and altruism in governing a young, modern state through the words of a respected and familiar figure, Isanoussi the elder, who is also the author's closest spokesperson.

Badian's socialist endeavour finds continuity in Niane's Chaka whose inspiration from Mofolo's eponymous novel served the Guinean playwright a more personal and immediate purpose in his interpretation.

Niane is best known for Soundjata ou l'épopée mandingue (1960), now a classic novel in Francophone African literature. This, and the fact that the story which precedes Chaka-Sikasso ou la dernière citadelle —-tells the story of the last bastions of resistance 
against French colonial forces in West Africa, reveals the author's intellectual stance and his passion for history: that of acquainting his readers with great figures from the continent's past.

Niane's aspirations for a modern and socialist-inspired African model of governance are located in the play's complex intertextual layers. But, just like Mofolo, Niane does not absolve Chaka of his crimes. Rather, by remaining faithful to Mofolo's portrayal of Isanusi, Niane retains the moral dilemma central to the novel. Despite Isanusi's wickedness, it is Chaka who, by making a pact with the diviner, choses power over good governance.

Ultimately Niane opened a topical debate for newly independent African governments: does the end always justify the means? Can leadership remain blameless? If not, when does a forgivable failure end and a tyrannical reign begin?

\section{Later versions}

The political preoccupations of the Francophone writers to have engaged with Mofolo's story of Chaka begin to change from the 1970's onward. They are concerned with national issues and their versions mirror the political realities of the continent, which are neither glorious nor optimistic.

In Togolese Sénouvo Agbota Zinsou's On joue la comédie (1975) for instance, Chaka is persecuted by the apartheid police. In the play, he is an actor called Chaka acting out Chaka's life. He is at once an actor and an actor of justice and this play about a play blurs out the distinction between the various 'realities' being acted out. Despite the lightness of the text and its happy ending, the central theme is dark. It is a plea for the black race to join the struggle against past and present injustices (Mabana 76).

Although Zinsou's play does not offer much new in terms of our investigation, his transposition of Chaka's 'situation' into apartheid South Africa is worth highlighting. Chaka, in Congolese Tchicaya U Tam'Si's Le Zulu is an antihero who commits suicide at the end of the play. Both the colonial era and apartheid are prognosticated: "Danger will come from there-beware of the sea-scum [...] The sea, everything that touches whiteness becomes hell!, warns Chaka!" (U Tam'Si 119 , my translation).

Importantly U Tam'Si also remains faithful to Mofolo's portrayal of the main protagonist. This text expresses the author's deep existential disillusionment with the realities of post-independence governance on the continent, a time when African dictators, like the Chaka in his play, are so imbued with their self-importance as past heroes that they become alienated from their own people (Mabana 146).

\section{Conclusion}

Because early Francophone drama was "a drama of social and political combat" (Conteh-Morgan 26-7), the combative aspect of the rewritings of Mofolo's story 
unifies the Francophone responses to Mofolo's narrative, emphasizing the political and ideological aspect of the novel's transculturation.

This is not simply evident in the content of the plays but also in their form. Part of the African Francophone playwrights' campaign was to reconnect with their past politically and culturally. Whether it is Fall, ${ }^{10}$ Badian or Senghor, the telling of the story as well as the way of telling it becomes a political act, something which has been shown to be true in Mofolo first.

Part of this revolutionary undercurrent in Francophone drama stems from the rigorous policy of assimilation which exercised a strong cultural control over France's colonial subjects before decolonisation. This left many West-African countries purged of their authentic cultural identity:

One can understand why, when Francophones later revolted against French rule, history either as a discipline or just as a theme in literature, especially in drama, should have become so attractive a weapon [...] they now saw no better tool with which to further their anti-colonial political ends. They came to the conclusion that as a condition for political and psychological freedom, they had to take part in, at the very least, if not take over, the production of their own self-image [...] The predilection of historical themes in the works of the dramatists among them is a reflection of the awareness of this need, and an attempt to meet it. By putting on stage the politico-military achievements of, say, Chaka (one of their favourite heroes) [...] the dramatists were doing several things. They were repudiating the myth of a history-less and insignificant past on which [French] colonialism based its claims; restoring theirs and their people's injured pride; rousing in the people a sense of patriotism and finally creating [...] myths and symbols for national self-consciousness and unity. (Conteh-Morgan 70)

This brings us to a second concluding comment to be made concerning the particularities of Francophone African drama, and that is that the central "thematic preoccupations of Francophone literary drama is the presentation of events and figures drawn from Africa's historical past" (Conteh-Morgan 61).

In fact, some of the authors discussed did not restrict themselves to (re)writing the story of King Chaka/Mofolo's Chaka. Senghor, as we know, was more generally concerned, in his poetry, with other historical figures of Africa's past such as the Kaya-Magan or the Queen of Sheba. This is also the case of Guinean writer Nénékhaly-Camara, ${ }^{11}$ who makes a strong association between Antar ${ }^{12}$ and Chaka as well as Niane who, as previously highlighted, wrote his most inspiring work on the legendary Soundjata.

Linked to this common desire to celebrate heroes from a pre-colonial African past is, of course, the need (revolutionary in nature) for the formation of a cultural identity. In their rewriting of Mofolo's novel, Francophone African writers have attempted to resurrect Chaka-a hero from the past—-to be used as a unifying myth 
and a source for national, and by extension pan-African consciousness. This is what was demonstrated by placing Mofolo's novel in its historical context. Clearly, this is how the Sotho writer intended to tell his story and this is how it was read in turn, making the original text a richly transculturated text. Because of his nation-building endeavour and the resulting deep-seated Zulu identity as well as Mofolo's own representation of the historical figure as such, the Zulu king, through Mofolo's ink, could become an inspiring catalyst in the quest for a coherent post-independence identity for these writers-who were all, one way or another, instrumental in the (re) building of their newly independent nations. It is clear from the versions discussed and the transculturation of Mofolo's text that the construction of a post-independence identity was strongly linked to pan-Africanist visions of a common history and resulting identity from which also stemmed nationalist ideals.

In The African Image, Mphahlele articulates his main unease with Negritude's precepts. He makes a cultural distinction between the African in British-settled territories ("a product of 'indirect rule"') and the French-speaking ("assimilated") African (Mphahlele 25). It seems that, for Mphahlele, this different cultural experience is at the core of the very different attitudes of these groups. This difference also motivates his main allegation against Negritude: the movement does not consider all social possibilities. When it advocates aesthetic action, such as a return to indigenous art, it blatantly ignores the South African "multi-racial" context—where, Mphahlele emphasises, Africans are "detribalized" (Mphahlele 27-8).

Mphahlele's disparaging arguments offer an interesting continuation to our hypothesis. If, as has been revealed, Chaka's transculturation into the negritudinist discourse through its literary rewritings lead to a specifically Senghorian definition of Africanity, at a time when French colonies were struggling for independence or grappling with the cultural and political complexities of their new-found independence, Mphahlele's passionate quarrel with its ideology is testimony to a stronger rapport between Southern African and Francophone African literatures than often acknowledged.

In the same way that there was, in the 1960s in South Africa, a political "conceptual refashioning" (Attwell 126) among black intellectuals, the rhetorical focus of our analysis, if we carry it further, must shift from an intertextual study to a broader investigation of the transmission of political cultures between Francophone intellectuals and Black Consciousness. We need to ponder the influence of Negritude, its Martinican approach in particular, on the Black Consciousness movement in South Africa.

Aimé Césaire and Frantz Fanon both very strongly influenced Steve Biko, the originator of the movement, in his philosophy and the enunciation of its defining concepts. Fanon's analysis of the impact of colonialism on the psyche of the colonised finds resonance in Biko's discourse. The idea that racism stems from the deliberate construction of blackness as a symbol of darkness (with all its consequential pejorative associations) pervades Biko's writing — such as the repeated references to the 
dehumanisation of the "black man" by white supremacist ideologies and the resulting association of African culture with barbarism (Biko 30-31). Evidence of the Martinican thinker's influence on Biko (whether implicit or in direct quotation) abounds in I write what I like (2004). Biko begins both parts of a paper presented at a student conference in 1971, by quoting Césaire (Biko 66-72). In this paper, he gives a definition of Black Consciousness, which is built around three key notions-recurrent throughout his writing and often repeated word for word elsewhere. These are: the idea of the uniqueness of the black world, the urgent need to take cognisance of this fact and the necessity to rewrite the African past. In strong keeping with Negritude's principle for the need of a (re)discovery of one's Africanity, these authors have sought to reconnect in an essential way and were able to do so through their idiosyncratic reading of Mofolo.

Biko substantiates this notion from Fanon's idea, quoted verbatim ${ }^{13}$ that colonialism robbed indigenous people of their history by distorting, disfiguring and destroying it and he believes that the re-appropriation of African history by Africans involves a re-discovery of past heroes such as, precisely, Moshoeshoe and Chaka (Biko 76). The idea strongly echoes Negritude's main ideological assertion. Once more, then, Chaka becomes synonymous with black power and solidarity. Biko, the South African activist, seems to echo the words of Senghor, the French-speaking African poet, who had seen in a Sotho novel nearly 20 years earlier, the symbolic power of a Zulu king.

\section{Acknowledgement}

This article is based on my doctoral thesis entitled "The transculturation of Thomas Mofolo's Chaka: Southern Africa and Francophone Africa in dialogue" (2007) completed at the University of the Witwatersrand, Johannesburg, South Africa.

\section{Notes}

1. Difacane in Sesotho: a period of war and chaos during the first half of the $19^{\text {th }}$ century in southern Africa, which was partly attributed to Chaka's expansionist politics.

2. This title is, in my opinion, more accurately and evocatively translated by Victor Ellenberger as Visions et Cauchemars in French because it retained the all-important idea of 'vision' which rests at the core of Mofolo's narrative construction and his hero's characterisation.

3. Named after one of King Dinuzulu's chieftains who, in 1906, fought against the imposition of the Poll Tax Bill imposed on all unmarried native males. It is estimated that between 2000 to 4000 Zulus lost their lives during clashes with the colonial police and that almost 5000 of them were brought to trial in the aftermath (Morris 611-2).

4. Mofolo was a highly politicised individual-he was for instance one of the founding members of the Basutoland Progressive Association (BPA, 1907), which had close dealings with the South African Native National Congress (1912) - later renamed the African National Congress.

5. King of the Mthethwa and Chaka's benefactor and mentor. He is an important figure because he evokes, no doubt, the figure of King Moshoeshoe, the founder of the Basotho nation. Moshoeshoe, who was loved by his people, was known for his fairness and great diplomatic skills.

6. A journal published in Paris and Dakar simultaneously. Présence Africaine offered black novelists and poets of the time an essential forum to have their works published. "Each publication showed the solidarity of a tight-knit group who aimed at saving the works of authors who wrote for their people. The journal was a platform where thinkers and writers, politicians and sociologists, elders and young academics 'attempted to define the originality of their Africanity that they tried to fit into the modern world'" (Diop in Kesteloot 207, my translation).He tells Donald Burness in a letter that he was intimately and politically inspired by Mofolo's novel (Burness 30, my emphasis). 
7. Chaka takes on a similar function for Biko who calls for the recovery of the history of the 'black man' by reclaiming the glory of previously vilified African heroes such as Chaka and Moshoeshoe (Biko 32), a plea that is recurrent in his pugnacious anti-apartheid rhetoric.

8. A form considered by Wole Soyinka to be the legitimate modern heir of traditional African ritual performance (Conteh-Morgan 24).

9. This could be translated as 'natural theatre' but what it really refers to is traditional storytelling, often based on classical stories and myths where characters are members of the spectators' community and could include sages (the wise elders), kings, queens, warriors, villains etc.

10 Malouga Fall's Chaka ou le roi visionnaire (1984) is reminiscent of older adaptations in form: a play written in simple language, to be performed on stage. Set in two parts, the story is led mainly by the character of the griot (called récitant in the play), who pronounces the opening and closing words of the play.

11. In Nénékhaly-Camara's Amazoulou (1970), Chaka, in keeping with Senghor's hero, is a tormented figure whose cruel deeds, committed for the good of his people, weigh heavily on his conscience.

12. African poet/warrior who died in 615. His long-standing mythical status in African oral literature became a classic of written Afro-Arabic literature in the $19^{\text {th }}$ century.

13. His words resonate throughout Biko's discourse. In a column written earlier, Biko uses the exact same words, this time without reference to their source: "[...] colonialists were not satisfied merely with holding a people in their grip and emptying the Native's brain of all form and content, they turned to the past of the oppressed people and distorted, disfigured and destroyed it" (Biko 31).

\section{Works Cited}

Attwell, D. "Mofolo's Chaka and the Bambata Rebellion." Research in African Literatures 18.1 (1987): 51-70. . Rewriting Modernity: Studies in Black South African Literary History. Scottsville: U of KwaZulu-Natal P, 2005.

Badian, S. The Death of Chaka. Trans. Clive Wake. Nairobi: O U P, 1968.

. La mort de Chaka. Paris : Présence Africaine, 1972.

Biko, S. I Write What I Like. Johannesburg: Picador Africa, 2004.

Burness, D. Shaka King of the Zulus in African Literature. Washington: Three Continents Press, 1976.

Conteh-Morgan, J. Theatre and Drama in Francophone Africa: A Critical Introduction. Cambridge: C U P, 1994.

Couzens, T. “Seydou Badian's The Death of Chaka." African Studies 33.3 (1974) : 186-8. Book review.

Fall, M. Chaka ou le Roi visionnaire. Paris: Les Nouvelles Editions Africaines, 1984.

Jouanny, R. Profil d'une œuvre: Ethiopiques (1956) Léopold Sédar Senghor. Paris: Hatier, 1997.

Kesteloot, L. Histoire de la littérature négro-africaine. Paris : Karthala-AUF, 2004.

Kunene, D. P. Thomas Mofolo and the Emergence of Written Sesotho Prose. Johannesburg: Ravan Press, 1989.

Lazarus, N. 1986. "The Logic of Equivocation in Thomas Mofolo's 'Chaka'." English in Africa 13.1. (1986): $41-60$.

Mabana, K. C. Des transpositions Francophones du mythe de Chaka. Frankfurt: Peter Lang, 2002.

Mofolo, T. Chaka. Trans. D. P. Kunene. Johannesburg: Heinemann, 1981. . Chaka, Une épopée Bantoue. Translated by V. Ellenberger. Paris: Gallimard, 1940.

Morris, D. The Washing of the Spears: The Rise and Fall of the Zulu Nation. London: Jonathan Cape Ltd, 1998. Mphahlele, E. The African Image. London: Faber, 1962.

Nénékhaly-Camara, C. Continent-Afrique suivi de Amazoulou. Honfleur: Pierre Jen Oswald, 1970

Niane, D. T. Chaka. Honfleur: Pierre Jean Oswald, 1971 Soundjata ou l'épopée mandingue. Paris: Présence Africaine, 1960.

Pratt, M. Imperial Eyes: Travel Writing and Transculturation. London: Routledge, 1992.

Roux, E. 1967. Time Longer than Rope: a History of the Black Man's Struggle for Freedom in South Africa. Madison: U of Wisconsin P, 1967.

Senghor, L. S. “Chaka.” Trans. J. Reed, J. \& C. Wake. Léopold Sédar Senghor: Prose \& Poetry. Oxford: O U P, 1965. . "Dialogue sur la poésie francophone." Poèmes. L. S. Senghor. Paris: Éditions du Seuil, 1984.

. Liberté I : Négritude et Humanisme. Paris: Éditions du Seuil, 1964.

U Tam'Si, T. Le Zulu. Paris: Éditions Nubia, 1977.

Zinsou, S. A. On joue la comédie. Lomé : Éditions Haho, 1984. 